\title{
Panti Wreda to Older Women: Diets Requirement, Access, and Malnutrition in Salatiga
}

\author{
Theresia Pratiwi Elingsetyo Sanubari ${ }^{1}$, Thomas Kornelis Tae ${ }^{2}$ \\ \{pratiwi.elingsetyo@staff.uksw.edu ${ }^{1}$, kornelistae@gmail.com ${ }^{2}$ \} \\ Faculty of Medicine and Health Sciences, Universitas Kristen Satya Wacana, Jl. Kartini 11A, \\ Salatiga, Indonesia ${ }^{1}$ \\ Yayasan Satukan Aksi Tunas Utama (YASATU), Non-governmental Organizational, Jl. Banteng \\ No.23, Kupang, East Nusa Tenggara ${ }^{2}$
}

\begin{abstract}
Projection of elderly number showed it reached until 22.66 million peoples $[9.03 \%]$ in 2017 . Furthermore, a high number of elderly also indicate the vulnerability of older women than older men. Panti Wreda (Nursing homes) as one responds from Indonesia government to provide older people requirement has a responsibility to provide regular food management for residents and suitable for every resident's nutrition needs based on health condition and age. Unfortunately, reality showed the opposite fact. Most older people have food secure but accessing food still become one challenge. Health status, which is related to the aging process needs proper nutrition requirement access accordingly this study want to explore an older women's condition in Panti Wreda regarding with diets requirement. This study uses a quantitative method with Food Frequency Questionnaire (FFQ) instrument and Body Mass Index (BMI) measurement to collect data. Panti Wreda Sosial Salib Putih gives other option for a resident to accessing food but aging process influence residents' food preferences. Poor food preferences eventually affect nutritional status and lastly provoke malnutrition status on older people, especially elderly women
\end{abstract}

Keywords: diets requirement, elderly women; food access; food preferences; malnutrition; nutritional status

\section{Introduction}

In Indonesia, the number of older persons significantly increase iscepievery year. The Indonesian Ministry of Health categorizes the elderly age group into the early elderly (46-65 years), late elderly (56-65 years) and the elderly (above 65 years). In 2017, there are an estimated 22.66 million older persons and will continually grow to 49.19 million in 2035 [1]. This situation doesn't only occur in Indonesia, but also worldwide. In Indonesia, older women are more vulnerable compared to older men. According to the Central Java Older Persons 
Profile (2016), the second-highest province of the number of older persons after Yogyakarta, the life-expectancy of older women is higher than the older men: the number of the older women with the status of death-divorce reach $55.51 \%$ compared to the older men which are $16.09 \%$. Moreover, there are $70.50 \%$ of older women who didn't complete their elementary school and never went to school. Whereas $47.57 \%$ of older men completed their education to the senior high school level, only $3.97 \%$ of older women did it. Consequently, not more than $38.22 \%$ older women who work while $63.88 \%$ of older men do [2].

An age-friendly city is an approach that Indonesia uses to address the growing number and the vulnerability of older women. It becomes one of the Sustainable Development Goals (SDGs) goals aims to establish healthy aging actions through optimizing the health, participation, and safety of older persons that contribute their quality of life [3]. The World Health Organization (WHO) describes 6 determinants for the age-friendly city. They are the economy, health, and social services, behavior, individual, physical and social. Not only they interact one to another, but also play a separate crucial role [4].

Panti Wreda is the Indonesian Government program on older persons under the Law No. 13/1998 on the Older Persons Welfare. Those regulations assert that Panti Wreda aims to assist the older persons living in the personal, family and community level. Furthermore, Panti Wreda as an institutional-based program is one of government embodiment to National Medium-Term Development Plan 2015-2019. Therefore, the government has increased the number of Panti Wreda. The Central Bureau of Statistics (2015) shows that there are 36 places of Panti Wreda in Central Java with 13,081 residents.

Panti Wreda is also one elaboration model in an operational system between government and non-government institution. One advantage from Panti Wreda is Panti Wreda has regular schedule activities for residents. One of the main activities from Panti Wreda prioritizes the implementation of social welfare for protection and rehabilitation of the elderly who are unable to meet the physical, spiritual and social needs. Panti Wreda is supposed to provide various assistances to replace the complementary functions of the family and home. Panti Wreda should provide accommodation with appropriate conditions, health services, and foodservice management.

Panti Wreda as food service management needs to be considered because it will have an effect on improving the health status of the elderly in general and the nutritional status of the elderly in particular. Panti Wreda needs to organize nutritional food based on health conditions and age of residents. Furthermore, Panti Wreda is told has optimal food if it meets the needs of nutritional and energy intake, safe, arouses appetite and is satisfying in the sense of meeting recommended portion standards [5]. If the food service management in Panti Wreda fails to meet the basic needs, it means residents still have vulnerable situation although they have permanent residence as Panti Wreda.

In other hands, although mostly older peoples have food secure, accessing food still becomes a challenge. Food choice will change along with price, convenience and physic health [6]. Other opinion says that food choice in older people will change because of some factors, such as income, education, time, location, health, and smell and taste's changing [7]. Personal preference also has a significant role in food choice [8]. Also, older people have a vulnerability to interest in food [9]. Health status, which is related to the aging process needs proper nutrition requirement access accordingly this study want to explore an older women's condition in Panti Wreda regarding with diets requirement. This study helps to discover older women's vulnerability in panti wreda. It will help panti wreda to government to do monitoring and evaluation their collaboration program for older people. 


\section{Methodology}

This study is using descriptive quantitative as a method. Panti Wreda Sosial Salib Putih is chosen regarding status as social panti wreda and oldest panti wreda in Salatiga. Thirteen older women who are up to 60 years old participate in this study. Three instruments are used in this study.

\section{Food Frequency Questionnaire (FFQ)}

Food Frequency Questionnaire (FFQ) is used to explore food pattern among residents at Panti Wreda Sosial Salib Putih. FFQ uses to obtain food consume data per day, per week, and month. Data collection process contain two parts. First is to exploring food that usually consumes among older people at Panti Wreda Sosial Salib Putih. Data become a basic questionnaire to ask by Food Frequency Questionnaire (FFQ).

\section{Body Mass Index (BMI)}

Body Mass Index (BMI) is used to explore nutritional status among residents at Panti Wreda Sosial Salib Putih. Inclusion criteria for residents are active residents and can communicate well at Panti Wreda Sosial Salib Putih. Data are collected from 21 older women and 3 older men.

\section{Mini Nutrition Assessment (MNA)}

Instrument MNA is used to identify malnutrition status among residents. Only data from 13 older women are collected. Data are collected from two phases. Frist is using MNA screening and second is use MNA assessment. MNA screening components are appetite, weight, mobility, psychologies condition or acute diseases, and BMI while MNA Assessment components are an environment, medication, skin problems, food frequency, protein consuming, fruit and vegetable consuming, fluid consuming, upper arm circumference, and calf circumference.

\section{Results and Discussion}

Panti Wreda Sosial Salib Putih started as a social activity to help the refugees of Kelud mountain eruption. Panti Wreda Sosial Salib Putih was officially established in 1966 and only accepts elderly from Salib Putih area. Javanese Christian Churches, Salib Putih Christian Social Foundation; and social department of Salatiga and Central Java control Panti Wreda Sosial Salib Putih. As panti wreda, Panti Wreda Sosial Salib Putih, which is an institutional foundation, has a responsibility in food service management. This function requires Panti Wreda Sosial Salib Putih to have a responsibility in food provider to ensure health status among residents.

Panti Wreda Sosial Salib Putih is doing a responsibility of providing three times meal for all residents. Preparation and food processing are usually in the morning shift for a whole meal in a day. A one shift process cause no food variant for three times meal. Caretaker maximized her responsible for food preparation in the morning at first shift and second shift only responsible for serving. Panti Wreda Sosial Salib Putih does not have a standard portion for individual residents. It only depends on food habit among residents. Limitation such as sugar consumed among diabetic patient just done if Panti Wreda Sosial Salib Putih has the availability of sufficient food. 
The common food processing techniques are fried, boiled, steamed, and pan-fried for a side dish, in which the elderly women need to pay attention when they eat saturated fats and trans fat. Vegetables usually boiled or make it as a soup. Types of side dishes that are commonly eaten are pepes tahu (wrapped up tofu with steamed coconut), bakwan jagung (fried corn), tempe mendoan (wrapped tempeh with flour dough), and semur telur (egg with soy sauce). Variant vegetables are papaya leaves, cassava leaves, carrot, bean sprouts, moringa oleifera, bean, and long beans. And for protein source only limited on tofu, tempeh, and egg. Panti Wreda Sosial Salib Putih only has budget 3000 rupiahs per resident per day for three times meal. Tight budget pursues caretaker to arrange a time to go to the marker. Caretaker usually goes to market once every 10 days.

A minimal budget makes Panti Wreda Sosial Salib Putih, give other option to residents to access different food source from outside. Usually, residents can get another food sourced from family or grocer who comes every Monday and Friday. Mostly family will send a dry food while grocer will sell crackers, satay, fried foods, fried noodle, and unprocessed tofu and tempeh. The price of a grocer is around $500-10000$ rupiahs. The most expensive food is satay while the cheapest is a cracker on 3 packages for 500 rupiahs. An overplus from the grocer is she can give a convenience through debt system. Resident can buy food without paying it directly and they can pay it irregular per day.

Affordable food access in the elderly will change diet quality and food preferences. Diet quality will change because of different background characteristics such as education, gender, and ethnicity. The aging process, especially older women will change their nutrition requirement, therefore, consume nutrient-dense foods and having a diet of adequate quality are a key to ensure elderly fulfilled their nutrition needs [13]. The difficulty in accessing food will affect elderly nutrition status and health [12]. This condition also becomes a challenge for Panti Wreda Sosial Salib Putih.

Residents' Panti Wreda Sosial Salib Putih, which only expects arriving food, will cause residents in food insecurity situation. Food insecurity situation among residents will affect their health and well-being [14]. Nutrition is one core determinant from healthy and active aging. Consume healthy food become one important factor in physiological well-being and better health and quality of life. Data in Panti Wreda Sosial Salib Putih, showed that $15 \%$ residents have Diabetes Mellitus history; 39\% have hypertension history; $7 \%$ have gout history, and 39\% have Upper Respiratory Tract Infection (URTI) history.

Food preferences also can change caused by food access and it showed from the Food Frequency Questionnaire (FFQ) data. Residents usually consume rice, tofu, sweet tea, and crackers. Limited food choice with poor nutrition contents among residents causes unbalance food habit. Unbalance food pattern among older people will cause high risk in health [15]. Older women who are already post-menopause will have a high risk in gout because of immunity degradation effect from estrogen hormone's absence [16]. It will increase vulnerability in older women in Panti Wreda Sosial Salib Putih.

The condition can be worse if older women have limited food access. Based on sex classification, a female has vulnerability regarding their process to post-menopause. The changing will cause hormone to unbalance in the body. It means at around 50 years old, female will has amount and function degradation from estrogen hormone; one of the most important hormones in the female's body. Hormonal changing will affect lipid metabolism and bone cause older women have a high risk of metabolic syndrome around $32.6-41.5 \%$ including cardiovascular abnormalities and diabetes mellitus type 2. In other hands, older women also have risk on bone mass degradation $1-3 \%$ until $35-50 \%$ in the end. Psychic changing will also occur and lead to poor lifestyles, such as unhappiness and low self-esteem 
[17]. It implies older women's hormone will impact health condition but nutrition requirement can help to reduce effects.

Individual food preference and nutrition requirement will change as long as aging. Pain and dependency will associate with the elderly's risk to nutrition fulfillment, especially elderly who has poor well-being, high dependent level ad low income [6]. Panti Wreda Salib Putih which is consists of older people from several generations will affect their food preference. The oldest and younger elderly are older women who born in 1928 and 1965. But food preference from residents not only come from the generation factor but also budget.

"I don't like the food here because every day is only tofu and tempeh. How I can consume that every day?" (Older women resident 1 )

"It is a blessing to can eat every day. Anything provided to me, I will eat it, such as vegetables, tofu, and tempeh" (Older women resident 2)

"It is enough for residents here, mostly we realize only has a limited budget but sometimes we get foods from outside. This Panti Wreda has many blessing" (Panti Wreda Worker)

"Many people come here and bring food to the residents. Sometimes we busy to cook it again and give it to residents and worker here. And for cooking, I will cook whatever we can get from the marker and that's enough for residents" (Panti Wreda Cooker)

Every person has a different learning experience with food and will cause different food preferences. Every person will learn about basic taste from biological differences [18] and in the end, can decide favorable food from learning experience started from infant [19] and the process will repeat on life [20]. A need for foods is a basic need, as psychology needs with clear purpose and simple to feel satisfied [21]. The different opinion among residents regarding regular food in Panti Wreda Salib Putih showed there are different experiences from residents before coming to Panti Wreda. Different generation, culture, and social-economic condition in every resident will influence food preferences choices [9] and will cause taste changing in older people.

The aging process impacts gustatory function changing and finally will change dietary intake. It also includes psychologies changing, such as taste receptor cells dysfunction, difficulties in maintaining oral health, and declining olfactory function [22]. Taste changing in older peoples will make them consume a small number of fruits and vegetables. Older peoples more like to consume sweet and softer food. The changing will influence older people's food choice, which is also influenced by the complex interaction of other sensory properties, for example, visual appearance and texture. On other hands, social factors such as convenience and price are also given effect for food choices [23]. Residents in Panti Wreda Salib Putih also experience the changing. It showed from residents who loved drink sweet tea. But Panti Wreda Salib Putih worker testifies that residents love to consume bitter vegetables. The unexpected finding showed that social-economy which is impact food access would continue to food preferences.

"Older people in Panti Wreda loves to eat bitter vegetables such as papaya leaves" - Panti Wreda Cooker

"Favorite food here is papaya leaves as vegetable source" - Panti Wreda worker 
Food access and food preferences changing in older peoples directly impact their nutritional status. Data showed 4 older women residents have under-nutrition status, 1 older woman resident has overweight status and 3 older women residents have obesity among 21 older women residents in total. While all older men residents have normal status; only 1 older man resident has an overweight status (Table 1). Elderly is a vulnerable group because their poor nutritional status that is caused by their aging process can continue until morbidity level and mortality consequence from malnutrition. The falls in high level, infection vulnerability, energy loss, and low moving level, late wound healing and confusion are reported as undernutrition consequences [24]. [25] inadequate household food security and poor economic situation will cause poor nutrition status. Also, the poor economic situation will affect the quality of life from the elderly, food security and food intake. In other hands, the food insecurity situation will increase the physical burden and in the end will impact dietary intake [26]. A circumstance is added by a tight budget from Panti Wreda Sosial Salib Putih.

Table 1. BMI Data in Panti Wreda Sosial Salib Putih

\begin{tabular}{ccccccc}
\hline No & Respondent & Sex & Weight & Height & BMI & Status \\
\hline 1 & 1 & F & 45 & 154 & 19,5 & Normal \\
2 & 2 & F & 45 & 156 & 18,7 & Normal \\
3 & 3 & F & 43 & 140 & 22,6 & Normal \\
4 & 4 & F & 37 & 142 & 18,5 & Normal \\
5 & 5 & F & 45 & 152 & 19,4 & Normal \\
6 & 6 & F & 45 & 144 & 21,7 & Normal \\
7 & 7 & F & 44 & 145 & 20,9 & Normal \\
8 & 8 & F & 56 & 153 & 23,9 & Normal \\
9 & 9 & F & 32 & 142 & 15,8 & Undernutrition \\
10 & 10 & F & 54 & 164 & 20,0 & Normal \\
11 & 11 & M & 82 & 168 & 29,0 & Overweight \\
12 & 12 & F & 40 & 138 & 21,0 & Normal \\
13 & 13 & F & 44 & 164 & 16,3 & Undernutrition \\
14 & 14 & F & 31 & 144 & 14,9 & Undernutrition \\
15 & 15 & F & 68 & 156 & 27,9 & Overweight \\
16 & 16 & M & 64 & 175 & 20,8 & Normal \\
17 & 17 & M & 60 & 164 & 22,3 & Normal \\
18 & 18 & F & 38 & 139 & 19,6 & Normal \\
19 & 19 & F & 99 & 150 & 40,0 & Obesities \\
20 & 20 & F & 34 & 153 & 14,5 & Undernutrition \\
21 & 21 & F & 52 & 152 & 22,5 & Normal \\
22 & 22 & F & 41 & 143 & 20,0 & Normal \\
23 & 23 & F & 75 & 163 & 28,2 & Obesities \\
24 & 24 & F & 73 & 160 & 28,5 & Obesities \\
\hline
\end{tabular}

Food insecurity will also influence high funding allocation for goods and services, that is connected with health promotion, better nutrition, and access for clean drinking water, sanitation, housing, and quality health services. As a developing country similar to the India situation, Indonesia has nutrition status that is connected with several factors, such as level of education, the standard of living and social status. Factors will influence malnutrition status on women especially in the situation of socio-economic status, culture, demography, and dietary characteristic. Malnutrition vulnerability in a developing country happens because women are a major share of managing the food security of families, as they are responsible for cooking and feeding all the family members apart from decision-making. Despite it, women also tend 
to neglect their health as a priority is placed on taking care of others [27]. On women, the intake of food will have a close connection with the purchasing power so that independent economic level will affect women access to get food intake [28]. Although, older women in Panti Wreda Sosial Salib Putih already in "independent" situation but caring sense toward other residents still exist. On other hands, lonely feeling still exists regarding them who apart from their family.

Vulnerability circumstance of women condition will ongoing from infant until elderly, mainly because functional status in elderly will depend from elderly's ability to do basic selfcare tasks and have an independent life, include food intake [28]. Malnutrition is caused by multi-factor, such as chronic illness, cognitive and physical impairments, depression, loss of appetite, stroke, eating dependencies, a problem with chewing, and swallowing difficulties [29]. The difficulty in accessing food and drink in Panti Wreda Sosial Salib Putih, as the institution-based program will increase malnutrition risk in residents. Malnutrition risk is mostly occurring in older women than older men because mostly older women have food insecurity situation and cannot an adequate amount of food. Older women in Panti Wreda Sosial Salib Putih show that 7 from 13 older women in total have malnutrition status (Table 2). The different situation can be caused by the psychological and physic condition, in other terms than economic and diets requirements in Panti Wreda Sosial Salib Putih. Mostly older women who are malnutrition have disability condition or come from a homeless background.

Table 2 MNA Assessment among older women in Panti Wreda Sosial Salib Putih

\begin{tabular}{cccc}
\hline Respondent & Age & Sex & MNA Assessment \\
\hline 1 & 75 & $\mathrm{~F}$ & Malnutrition \\
2 & 80 & $\mathrm{~F}$ & Malnutrition \\
3 & 81 & $\mathrm{~F}$ & Malnutrition \\
4 & 79 & $\mathrm{~F}$ & Malnutrition \\
5 & 89 & $\mathrm{~F}$ & - \\
6 & 84 & $\mathrm{~F}$ & Malnutrition \\
7 & 73 & $\mathrm{~F}$ & Malnutrition \\
8 & 70 & $\mathrm{~F}$ & - \\
9 & 70 & $\mathrm{~F}$ & Malnutrition \\
10 & 64 & $\mathrm{~F}$ & - \\
11 & 58 & $\mathrm{~F}$ & - \\
12 & 91 & $\mathrm{~F}$ & Malnutrition \\
13 & 66 & $\mathrm{~F}$ & - \\
\hline
\end{tabular}

The aging process also increases malnutrition risk because physiological change, include more rapid and longer satiation, dental and chewing problems, being less hungry and thirsty, and impairments in smell and taste, and can become a trigger to eating behavior changing. Slow chewing in elderly, consume limited meals and snack will trigger lower food consumption and ultimately, to weight loss. Although elderly only need low energy requirement the requirements for many other nutrients may not change, or may even increase. And for nutrient intake, usually elderly has risk on protein, fiber, and some micronutrients intake (13). Malnutrition situation in older women is more susceptible than older men also caused by social and cultural perspective. The social view has led the older women are more vulnerable than the older men. The older women are trapped between the social belief and health problems, such as domestic violence and elder abuse. The domestic violence which inevitably occurs to women will frequently happen as the women get old [30]. The neutral- 
gender condition is utilized to understand elder abuse. It often omits the underlying and systematical power structure between women and men. Moreover, it becomes a challenge to rude behavior. As a consequence, the discussion of elder abuse doesn't acknowledge the different burden between older women and older men. Therefore, it is very rare to address violence against older women [30] and limited understanding of the meaning of violence lead difficulty to the identification.

Inability Panti Wreda Sosial Salib Putih to provide diets requirement can increase health problems among older women residents. This situation should be a concern not only Panti Wreda but also Indonesia government to create a reliable program for Panti Wreda as collaboration institution. But different older people background and individual needs require to be considered while create a program. A different point of view regarding diet requirement and health can become an obstacle to bring a program to older people.

\section{Conclusion}

This research wants to explore an older women's condition in Panti Wreda regarding diets requirement. Older peoples who have food secure but still vulnerability in accessing food indirectly or directly affect older people food preferences, nutritional status until malnutrition. Panti Wreda Salib Putih is an institution-based program with regular food management but has difficulty to provide secure basic needs like food to residents. Panti Wreda Salib Putih only can provide 3000 rupiahs per day per person and give unstable food access with poor nutrition foods. It affects the poor preference of food, with mostly rice, tofu, sweet tea, and crackers. Poor nutritional status also becomes a problem, especially in older women regarding their vulnerable condition in economic, social, cultural factors. In the last, malnutrition becomes a common situation among older women than older men.

\section{References}

[1] Kemenkes RI. Analisis lansia di Indonesia. Pus data dan Inf [Internet]. 2017;1-2. Available from: www.depkes.go.id/download.php?file=download/.../infodatin lansia 2016.pdf

[2] Badan Pusat Statistik Provinsi Jawa Tengah. Profil Lansia Jawa Tengah 2016. 2016.

[3] United Nations. SDGs ... Sustainable Development Knowledge Platform [Internet]. United Nations. 2018 [cited 2018 Nov 30]. Available from: https://sustainabledevelopment.un.org/topics/sustainabledevelopmentgoals

[4] World Health Organization. Global Age-friendly Cities: A Guide. 2007. 1-82 p.

[5] Damjan Zelenik, Tatjana Persuh TJ. Practical Approach to Nutritional Support in Nursing Home. Clin Nutr ESPEN. 2016;14:53-4.

[6] Peura-Kapanen L, Jallinoja P, Kaarakainen M. Acceptability of convenience food among older people. SAGE Open. 2017;7(1).

[7] Koehler J, Leonhaeuser IU. Changes in food preferences during aging. Ann Nutr Metab. 2008;52(SUPPL. 1):15-9.

[8] Donini LM, Poggiogalle E, del Balzo V. Food Preferences in the Elderly. Mol Basis Nutr Aging. 2016;(February 2018):121-6.

[9] Vabe M, Hansen H. The Relationship between Food Preferences and Food Choice : A Theoretical Discussion. Int J Bus Soc Sci. 2014;5(7):145-57.

[10] Food and Agriculture Organization of the United Nations. Food Security and Protracted 
Crisis. Policy Br [Internet]. 2006;(2):1-4. Available from: http://www.fao.org/forestry/13128-0e6f36f27e0091055bec28ebe830f46b3.pdf

[11] Rachman P. H, Ariani M. Ketahanan Pangan: Konsep, Pengukuran dan Strategi. Forum Penelit Agro Ekon. 2002;20(1):12-24.

[12] Huang DL, Rosenberg DE, Simonovich SD, Belza B. Food Access Patterns and Barriers among Midlife and Older Adults with Mobility Disabilities. J Aging Res. 2012;2012:18.

[13] Robinson MS. Improving nutrition to support healthy ageing: what are the opportunities for intervention? In: Improving nutrition in metropolitan areas. 2017. p. 1-8.

[14] Fernandes SG, Rodrigues AM, Nunes C, Santos O, Gregório MJ, de Sousa RD, et al. Food Insecurity in Older Adults: Results From the Epidemiology of Chronic Diseases Cohort Study 3. Front Med. 2018;5(July):1-12.

[15] Tae TK, Sanubari TPE, Rahardjo M. Perubahan Pengetahuan Tentang Jenis Makanan Dan Cara Pengolahannya Pada Pengurus Lansia Perempuan Postmenopause Di Panti Wreda Salib Putih, Kota Salatiga. J Kesehat Kusuma Husada. 2019;24-31.

[16] Koyoingan AS, Kundre R, Lolong J. Hubungan Status Gizi dengan Gout Arthitis pada lanjut Usia Di Puskesmas Wawonasa Manado. e-Journal Keperawatan. 2015;3(3):1-7.

[17] Kaaja RJ. Metabolic syndrome and the menopause. Menopause Int. 2008;14(1):21-5.

[18] Tourila H. Sensory perseption as a basis of food acceptance and consumption. In: MacFie H, editor. Consumer-led food product development. England: Woodhead Publishing Limited; 2007. p. 34-59.

[19] Capaldi ED. Conditioned food preferences - Sclafani.pdf. 2015;28(February 2013):5380.

[20] Marion Nestle, Rena Wing, Learn Birch, Lorelei DiSogra, Suzette Middleton, Madeleine Sigman-Grant, et al. Behavioral and Social Influences on Food Choice. Nutr Rev [Internet]. 1998;56(5):50-74. Available from: https://deepblue.lib.umich.edu/bitstream/handle/2027.42/75438/j.17534887.1998.tb01732.x.pdf?sequence $=1$ \&isAllowed $=y$

[21] Mela DJ. Food choice and intake: the human factor. Proc Nutr Soc. 1999;58(3):513-21.

[22] Sergi G, Bano G, Pizzato S, Veronese N, Manzato E. Taste loss in the elderly: Possible implications for dietary habits. Crit Rev Food Sci Nutr. 2017;57(17):3684-9.

[23] J.L. L, C.S. R, C.O. R, D.L. R, D.S. W, K.L. B. A multidimensional approach to understanding under-eating in homebound older adults: The importance of social factors. Gerontologist [Internet]. 2008;48(2):223-34. Available from: http://www.embase.com/search/results?subaction=viewrecord \&from=export\&id=L3517 05987

[24] Leslie W, Hankey C. Aging, Nutritional Status and Health. Healthcare. 2015;3(3):64858.

[25] Charlton KE, Rose D. Nutrition among Older Adults in Africa: the Situation at the Beginning of the Millenium. J Nutr. 2018;131(9):2424S-2428S.

[26] Bukunmi AA, Jeremiah CO. Nutritional status, household food security and dietary diversity of the elderly residing in Ilaro, Ogun state , Nigeria. 2018;

[27] Vatsala L, Prakash J, Prabhavathi S. Food Security and Nutritional Status of Women Selected from a Rural Area in South India. J Food, Nutr Popul Heal. 2017;1(2: 10):1-8.

[28] Agarwalla R, Saikia A, Baruah R. Assessment of the nutritional status of the elderly and its correlates. J Fam Community Med. 2015;22(1):39.

[29] Mamhidir AG, Kihlgren M, Soerlie V. Malnutrition in elder care: Qualitative analysis of ethical perceptions of politicians and civil servants. BMC Med Ethics. 2010;11(1). 
[30] Hightower J. Abuse in later life: when and how dose gender matter? In: Gutman G, Spencer C, editors. Aging, Ageism, and Abuse. Burlington: Elsevier Inc.; 2010. p. 1730. 